Journal of Southeast Asian

Volume 12

Issue 250 Years of Model Minority Stereotype

Research

2017

\title{
Teaching for Social Justice: (Post-) Model Minority Moments
}

Candace J. Chow

University of Utah, candace.chow@utah.edu

\section{Dr. Nicholas Hartlep}

Metropolitan State University

Follow this and additional works at: https://docs.lib.purdue.edu/jsaaea

Part of the Bilingual, Multilingual, and Multicultural Education Commons

\section{Recommended Citation}

Chow, Candace J. (2017) "Teaching for Social Justice: (Post-) Model Minority Moments," Journal of Southeast Asian American Education and Advancement. Vol. 12 : Iss. 2, Article 3.

DOI: $10.7771 / 2153-8999.1155$

Available at: https://docs.lib.purdue.edu/jsaaea/vol12/iss2/3

This document has been made available through Purdue e-Pubs, a service of the Purdue University Libraries.

Please contact epubs@purdue.edu for additional information.

This is an Open Access journal. This means that it uses a funding model that does not charge readers or their institutions for access. Readers may freely read, download, copy, distribute, print, search, or link to the full texts of articles. This journal is covered under the CC BY-NC-ND license. 


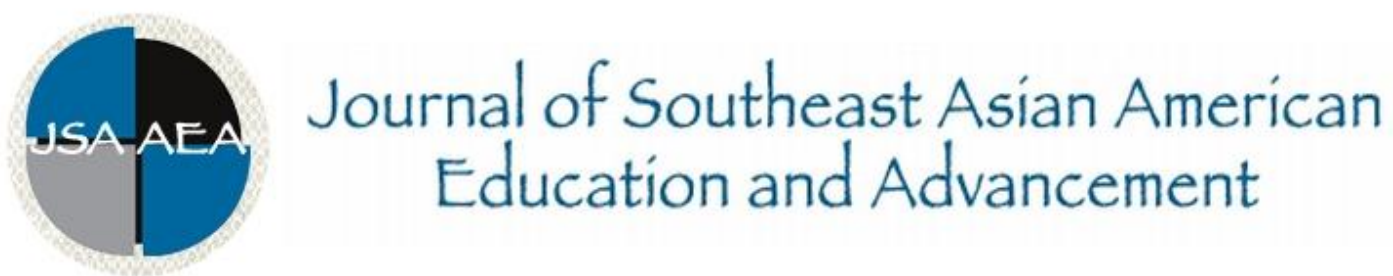

Vol. 12 Iss. 2 Special Issue (2017) $\quad$ www.JSAAEA.org

\title{
Teaching for Social Justice: (Post-)Model Minority Moments
}

\author{
Candace J. Chow \\ University of Utah
}

\begin{abstract}
Much of the literature on model minority discourse focuses on impacts of this stereotype on students. Though the Asian American teacher population is small, it is useful to consider how this stereotype also affects the work of Asian American teachers, their identities, and their pedagogy. This article examines how two Southeast Asian American teachers envision teaching for social justice. Although it appears that these two teachers are products of the model minority stereotype because they have succeeded educationally, a closer examination of their educational pathways reveals that many obstacles, including poverty and a lack of English fluency, could have easily prevented them from being educationally successful if not for the intervention of their teachers. Analyzing these teachers' narratives allows us to reflect on how the model minority stereotype produces moments of tension for Asian American educators. At the same time, an examination of these teachers' dedication to teaching and mentoring lowincome students of color allows us to imagine a post-model minority moment, where Asian American teachers disrupt the model minority stereotype by working to advance the education of all students of color.
\end{abstract}

Keywords: Asian American, teachers, identity, pedagogy

\section{Introduction}

Scholarship on Asian Americans in education has focused heavily on the student experience, both at the $\mathrm{P}-12$ and higher education levels. Much of this literature explores how Asian American students are racialized by and respond to the model minority stereotype. (A detailed list of such scholarship can be found in Hartlep, 2013). In contrast, 
fewer studies on Asian American teachers exist, particularly with regard to how they are influenced by this stereotype (Morita-Mullaney \& Greene, 2015). This paper explores how two Southeast Asian American teachers negotiate the model minority myth while actualizing their visions of teaching for social justice.

The Asian American population is only 6\% of the nation's population (U.S. Census, 2015), and Asian American teachers are only 2\% of the total teaching force (NCES, 20112012). The paucity of Asian American teachers has been the subject of many earlier studies on Asian American teachers (Gordon, 2000; Rong \& Preissle, 1997). Such studies conclude that the lack of Asian American teachers is largely due to personal choice. Asian Americans do not go into teaching because they feel inadequate to work with students of different races (Gordon, 2000), they fear failure (Gordon, 2000), they fear discrimination from students, colleagues, and parents (Gordon, 2000; Rong \& Preissle, 1997), and they face parental pressure to secure a high-status and high-paying career (Gordon, 2000; Rong \& Preissle, 1997). Moreover, unlike African American and Latino teachers, some Asian American teachers report not seeing their ethnicity as playing an important role in their teaching careers (Gordon, 2000). While these studies imply that Asian underrepresentation is the aggregate result of personal choice, it is also possible that Asian Americans do not become teachers because racial discourses send implicit and explicit messages to Asian Americans that they do not belong in such professions.

In fact, other literature shows that teacher education programs can be culturally exclusive (Sheets \& Chew, 2002), that both cooperating teachers and children in classrooms can play a role in enacting racism toward pre-service Asian American teachers (Newton, 2003), and that Asian American teachers feel silenced by students, stereotyped by colleagues, and doubted by parents (Goodwin, Genishi, Asher \& Woo, 2006; Ngyuen, 2009; Suzuki, 1998). It is only when Asian American teachers feel comfortable speaking about race in the classroom that they incorporate issues of race and racism into their curriculum in explicit ways (Philip, 2014; Suzuki, 1998). Collectively, these studies show how Asian American teachers have been silenced by teacher education programs and by interactions with their peers, their students, and their students' parents.

This article seeks to enhance our understandings of Asian American teachers' classroom experiences, particularly around their negotiation of social identities (including but not limited to race, ethnicity, gender, and class) and how their identities influence their pedagogy. I examine how two Southeast Asian American teachers negotiate the stereotypes that are associated with the model minority in the context of their own schooling experiences and with respect to teaching low-income students of color. I explore how the model minority stereotype produces moments of tension for these teachers and their students.

I begin the following section by exploring how the model minority stereotype can be used as a framework for understanding identity and pedagogy. Following this conceptual framework, I explain my methods and present my data. My data analysis section concludes with my participants' responses to the data analyses. Finally, I conclude by providing recommendations for how to equip all teachers to teach for social justice. 


\section{Understanding Teachers' Identities through the Model Minority Stereotype}

Understanding teachers' narratives is essential to understanding how teachers' identities are connected to their work (Connelly \& Clandinin, 1999; Knowles, 1992) because the identity a teacher embodies in the classroom affects how and what they will teach. Alsup (2006) explains that learning to be a teacher involves "doing borderland discourse", a process by which pre-service and beginning teachers learn how to move from one discursive space to another, such as from a student to a teacher. Importantly, Alsup argues that adopting a teacher identity is harder for some teachers than others because a teacher's identity is comprised of multiple components. Specifically, she says: "If a new teacher is not a member of the middle class, White, female, and heterosexual, the difficulty of the transition is exaggerated" (p. 7). Thus, when a beginning teacher is not already part of the discursive spaces that are normalized in teaching - that is, middle-class, White, female, and heterosexual - they have more borderlands to negotiate and may encounter more struggles in the process of becoming a teacher. While White teachers struggle to understand how to incorporate different aspects of themselves and others' perceptions of them into a cohesive teacher identity, Asian American teachers must also contend with how to negotiate how others perceive them because of their race.

Because race and ethnicity tend to be salient identifiers for teachers of color, it is important to examine how they live out their cultural identities in the classroom (Clark \& Flores, 2001). Yet, as Takaki (1989), Lowe (1991), Espiritu (1992), and Ngo (2010) have suggested, not all people of color identify with their race or ethnicity in the same way, or to the same degree. Some teachers are not conscious of how their ethnic and racial identities affect their role in the classroom and instead must learn how to embrace, negotiate, and incorporate these identities into their teaching (Clark \& Flores, 2001; Cozart, 2010; Miller, 2008; Nyugen, 2009). Other studies have shown that teachers of color who are aware of their racial and ethnic identities bring something unique to the classroom because they can serve as "agents of change" (Villegas \& Lucas, 2002, as cited in Achinstein \& Ogawa, 2011). For example, teachers of color may use personal experience to connect to their students (Ladson-Billings, 1994; Mensah, 2009). Other teachers tailor their teaching to be relevant to students' prior experiences (Brown, 2009; Gomez, Rodriguez, \& Agosto, 2008; Wong, 2008). Still other teachers engage in subversive education in order to challenge the notion that students of color are lacking in ability (Achinstein \& Ogawa, 2011; Arce, 2004; Farrugio, 2009; Foster, 1997; Frederick \& View, 2009). Interestingly, while some scholars posit that students prefer race-matched teaching, which is when a teacher's race matches the student's race (Dickar, 2008; Ochoa, 2007), other studies find that students of color deem teachers of color as culturally suspect (Achinstein \& Aguirre, 2008). In all of these cases, a teacher's identity and his/her understanding of that identity is important and relevant to classroom relationships and events. In particular, I am interested in understanding how teachers with different racial identities from those of their students negotiate these borderlands. I use Ladson-Billings' (1994) work in particular to help me understand this concept, as she has written about White teachers' abilities to successfully reach their African American students. To understand Asian American teachers' identities, and in this case, Southeast Asian American teachers' identities, it is important to recognize how Asian Americans are racialized, and the various ways in which these discourses are adopted. 
The racial paradigm of the United States stresses Black-White relations (Okihiro, 1994; Wu, 2003) and renders Asian Americans invisible (Lee, 2005). When Asian Americans are included, they are typically framed in one of two ways. The first is within an historically situated discourse, that of "yellow peril" — as dangerous and untrustworthy foreigners (Wu, 2003). This image is hardly flattering. The second way Asian Americans are framed is along a hierarchical racial continuum, as better-than-Blacks but not-as-good as Whites (Kim, 1999). They are located in a third space (Kim, 1999), triangulated between Blacks and Whites. Instead of attributing Asian American financial and academic success to immigration patterns, it has been credited to hard work and inherent intelligence (Prashad, 2000). By upholding Asian Americans as the model minority (Tuan, 1998; Kim, 1999), other minority groups are framed as less-than. While this positive stereotype might be considered flattering especially when compared to being a "yellow peril," because Asian Americans are only given "honorary White" status through this myth, they do not actually benefit from White privilege. Moreover, the illusion of being better-than has created tensions between Black and Asian American communities, resulting in a division, rather than a pooling of resources, to combat racist ideologies and practices (Hayes \& Hartlep, 2013).

In addition, by framing Asian Americans as successful achievers, their differing needs are overlooked. For example, even when students are not high-achieving, they are assumed to do well in school (Wong, 1980). The essentializing power of the model minority myth has played the biggest role in the racialization and racial lumping of Asians in the United States, and has made it difficult for many struggling Asian American students to actually get the help they need from teachers (Nance, 2007). Teachers do not see past students' Asian appearances and do not recognize that they each have different learning abilities; instead their individual needs remain invisible.

Further complicating this flawed perception of Asian Americans is the fact that educational attainment differs across ethnicity. While East Asian and South Asian groups have historically been educationally and financially successful because of their immigration circumstances (Lee, 2009), many Southeast Asian Americans face barriers with respect to these issues (National Commission on Asian American and Pacific Islander Research in Education/CARE; Lee, 2009). In large part because the immigration circumstances for Southeast Asians have been very different from those of East Asian and South Asian groups, Southeast Asian ethnic groups, including Vietnamese, Cambodians, Laotians, and Hmong, experience much lower rates of educational attainment (CARE, 2015; Chiang, Fisher, Collins, \& Tin, 2015). As these lower-achieving students do not conform to normative standards of the model minority, Southeast Asians have been "blackened" (Lee, 2005), and portrayed as having "urban" and "hip hop" identities (Lee, 2005; Ngo, 2010) rather than being associated with the "Whitened" identities so often associated with East Asian Americans.

It is significant to note that the model minority discourse not only shapes how Asian Americans are viewed by non-Asians, but that the stereotype also influences how Asian Americans view themselves. Some Asian Americans believe that studying hard and getting good grades is inherently cultural, and that parents who are not overly pushy about getting A's are less "traditionally" Asian (Chow, 2014). They believe that playing the role of the model minority is positive, and that conforming to these standards is a way of earning respect from White Americans (Lee, 2009). Other Asian Americans challenge the 
stereotype by adopting "a culture of resistance" (Lee, 2009; Ogbu, 1987). They actively seek to defy the practices that are deemed normative by the stereotype, and take pride in their different approach to school. Finally, there are also Asian Americans who view race in more political terms. These Asian Americans believe in challenging racism and in coalition building with other communities of color, and are more inclined to identify as people of color than as just Asian American (Lee, 2009; Philip, 2014).

There are competing discourses surrounding who Asian Americans are and who Southeast Asian Americans are, particularly with respect to education. While the Southeast Asian teachers in my study may be stereotyped according to the discursive regimes the model minority stereotype imposes on them, their lived experiences reflect this trajectory in uneven ways. Additionally, there are many Asian American teachers who work in lowincome neighborhoods and with students of color. It is important to explore what happens when Asian Americans who identify not just as Asian American, but also as people of color, choose to teach these students, such as the two in my study.

\section{Methods}

\section{Data Collection}

The data for this article are drawn from a larger, multiple case study on Asian American teachers. The teachers in the larger study represent a variety of Asian ethnicities and immigrant histories, and teach different age groups and subjects in different school settings across the country. I employed purposive sampling (Patton, 2001) to identify participants, both through personal contacts and through snowball sampling.

At the time this study was conducted, the two teachers of focus in this paper, who were chosen for this paper because of their Southeast Asian heritage, taught in urban schools: one in South Minneapolis, and one in New York City. I conducted one of the interviews over Skype, and the other one over the phone-participants were given a choice between a phone and video interview. Using technology to conduct my interviews enabled me to interview teachers from different parts of the country rather than just one location (Hanna, 2012), adding to the diversity of experiences in my sample.

I audio-recorded and transcribed my interviews. The initial semi-structured interviews lasted 60 to 90 minutes. Follow-up interviews, which were conducted the following school year, lasted 30 to 60 minutes. I employed member-checking (Saldaña, 2009) as a way to ensure the validity of the data I had collected for this larger study. Additionally, I conducted a third interview with both participants while writing this paper to include my participants in a conversation to further my analyses.

\section{Positionality of Researcher}

I am a former secondary English literature teacher, and my interest in studying Asian American teachers is borne out of my own classroom experiences. These identities that I had in common with my participants - both professionally and racially - served as a point of connection. Both teachers were interested in participating because no one had ever asked 
them what it was like to be an Asian American teacher, and the chance to reflect on these experiences was intriguing. There were several times they would begin to tell a story, and then stop and say "you know," to indicate that they felt I had insider status (Creswell, 2009). At the same time, I recognize that my identities diverge from those of my participants, particularly the two of focus in this paper. I do not share the immigration history or class status of their families, nor are we from the same ethnic or language backgrounds. There are also professional differences in our pathways to becoming educators, and in the grades/subjects we teach. Additionally, as an East Asian American, I realize that my identity has been shaped by the model minority stereotype in different ways from my Southeast Asian American participants.

Thus, while our common identities certainly served as a point of entry for me in gaining trust from my participants, I recognize that my experiences are not the same as theirs. Reflexivity as "introspection" is an element that I have examined carefully in analyzing my data (Wells, 2011). It has been important to make a conscious effort not to superimpose my own experiences, beliefs, and opinions on those of my participants. This is one reason I invited these two participants to join me in my analysis of the original project's data-to ensure that I was representing their voices with authenticity. Additionally, while I could have easily analyzed the information they already provided and stopped there, this left me with a simplistic view of their educational and teaching experiences, and a stunted understanding of the role of Asian Americans in classrooms. In order to arrive at a more nuanced understanding of the complexities of being Asian American in educational spaces, I found it necessary to invite my participants to comment further on the roles of race and privilege in their classroom experiences, both as students and as educators.

\section{Data Analysis}

I begin this section by providing biographical sketches of my two participants, Bounmy and Mai-Li (both pseudonyms), the two teachers whose narratives I highlight in this article. From there, I highlight three themes that emerged from their narratives. I end each of these sections by posing questions that illuminate the tensions of being Asian American that are not fully addressed by the interview data I originally collected. Finally, I conclude the data analysis section with responses from the participants' third interviews. The responses do not simplify the complexities of the participants' positionalities, but instead provide greater understandings of these nuances.

\section{Bounmy}

Bounmy is from Laos, and spent the first two years of her life in a refugee camp in Thailand before immigrating to the Midwest in the 1980s. She is the youngest of three daughters. She describes her childhood neighborhood as poor and "rough," which is one reason she chose to attend a magnet high school that was farther away from her home than her local high school. 
Bounmy was a fifth year high school math teacher when I conducted my first interview with her. Bounmy has taught at two different schools, both of which are located in low-income neighborhoods in Minneapolis. The student population in her first school was entirely African American. The population in her second school is comprised of African immigrants. When I spoke to her the first time, she talked about how proud she was to have stayed in teaching for five years, but mentioned that she was starting to experience burnout. She was in the process of pursuing a Ph.D. in Math Education, and talked about how although she wanted to remain in education, she had doubts that she would remain a classroom teacher much longer. By the time I conducted my follow-up interview with her, Bounmy was a full-time Ph.D. student in STEM Education. She had left the classroom but remained a consultant at the two schools where she had been a teacher. Bounmy has since completed her dissertation, and is currently working with undergraduate students as the Science, Technology, Engineering, and Mathematics Education Coordinator at a university in the Bay Area.

\section{Mai-Li}

Mai-Li was born in Vietnam and immigrated to the United States with her parents as refugees when she was four years old. Mai-Li is the older child of two and grew up in a housing project in Seattle, in a neighborhood with many other Southeast Asian refugee families. She attended her local elementary and middle schools, but under the advisement of her teachers, bused to a comprehensive high school farther from home, where the "academics are much more rigorous."

Mai-Li was in her second year of teaching through Teach for America when we spoke for the first time. She had transferred from her first school in the South Bronx for safety reasons (one of her students in her first school had become violent toward her and other adults in the school) to a school in Chinatown, Manhattan. The student population at her school in the Bronx was largely Latino, while the students in the Chinatown School are mostly Chinese. However, since she is a special education teacher, her students were a more racially diverse group than both schools' general populations. After taking a break to finish her Master's degree full-time, Mai-Li resumed teaching. She is currently faculty at a middle school in the Pacific Northwest.

\section{"It Was Through My Teachers"}

At first glance, it appears that both Bounmy and Mai-Li are successful embodiments of the model minority stereotype. They were both raised in low-income neighborhoods by parents who do not have college degrees, work low-wage jobs and who lack English fluency, and yet they went on to graduate from college, earn graduate degrees, and hold professional careers. Bounmy and Mai-Li fit the image of being "exemplary minorities who gain success through sheer effort and determination" (Lee, 2009, p. 7). However, what is missing from this picture are the concerted efforts of their teachers, whom both participants credit with their success. For example, Bounmy recalls: 
Between 3rd and 5th grade ... teachers would pull me out of [the] classroom because they thought I was talented ... so because I had teachers who took the time to realize that I had a gift, you know, I thought that that kind of contributed to my positive feelings toward school . . . I had people who really believed in me; they happened to be math teachers, but a few weren't . . . All of my teachers were very supportive of my plan. Some of them even helped me find scholarships.

Similarly, Mai-Li says:

I really had teachers who really cared. They made ... my parents feel very welcome ... it was a very inclusive place ... I think it was through my teachers in middle school who were like, you need to go to Mountainside [for high school]. This is what you need to do ... A And they told my parents ... and so my teachers sort of sent me to Mountainside and my parents were very supportive . . . I had a teacher who played lacrosse.... she was like, you should play a sport ... she bought me a lacrosse stick...helped me pay for the fee to be on the lacrosse team....

Bounmy and Mai-Li's narratives reveal that their success is not merely a product of determination or effort, or even of opportunity. Instead, teachers who cared enough to invest in their futures created opportunities for them. Teachers recognized that both women were academically talented, and nurtured that promise. In addition, their teachers fostered their development through monetary means - in Bounmy's case, by helping to fund or find funding for her post-secondary education, and in Mai-Li's case, by providing the means for her to participate in extracurricular activities that she could include on her college application.

Although Bounmy and Mai-Li's parents encouraged them to earn an education, they did not have the knowledge or means to enact a "concerted cultivation" parenting style (Lareau, 2011) because they did not know to place them in extracurricular activities, or how to navigate the college admissions process. Instead, their teachers took on this role and helped them achieve their academic goals. Could they still have succeeded through sheer determination and effort? Possibly. But, it is clear that having several mentors who helped guide the way made a difference in their lives.

Thus, Bounmy and Mai-Li's narratives add some complexity to the model minority stereotype. Their academic achievements, while in alignment with the stereotype, are not merely products of their race, or ethnicity, or because of their "Asian" work ethic (Lee, 2009). Instead, their accomplishments are the outcomes of ongoing encouragement and cultivation from teachers who knew how to guide their educational pathways. It could even be argued that their teachers' interventions are what kept Bounmy and Mai-Li from adopting an "oppositional" stance towards education (Ogbu, 1987). Both could be considered involuntary immigrants, whose families immigrated to escape an inhospitable political climate, rather than simply to attain a better lifestyle. Ogbu (1987) does not include Asian refugees in his examples of involuntary immigrants. However, other scholars have used his work to explain how some Southeast Asian Americans adopt the notion that educational success is a path toward financial success, and others resist education as a personal pathway toward mobility (Chiang et al., 2015; Lee, 2005). Clearly, much of Bounmy and Mai-Li's success is owed to their parents' beliefs that educational success is 
a trajectory towards economic success and social mobility. It is worth considering whether having teachers who cultivated this belief further reinforced these ideas.

An additional point to consider is whether their teachers chose to help and encourage them because they are Asian American. That is, did their teachers expect them to do well because they themselves had been socialized to believe that Asian American students achieve? Would their teachers have recognized and encouraged their talents if they did not look like model minorities? This a question we will return to later.

\section{Teaching for Social Justice}

Given that their teachers were such a big influence on their lives, it is not surprising that Bounmy and Mai-Li are driven to teach to "give back" to students what was given to them. Both teachers discuss how important it is for them to teach and serve specific communities - the types of communities they grew up in. Bounmy reflects on why she works with low-income students:

The reason why I wanted to be a teacher was to reach a certain demographic. So for me not to teach at a low-income school would ... I think all students deserve to have good teachers ... what my teachers did I wanted to do for my students, which was help me find scholarships, help them in whatever way they needed . . . I've written checks to colleges for students that I thought could use that boost or lift. Because someone has done it for me for many years.

Mai-Li has similar motivations:

At [my school in the Bronx] during the summer, every Friday, I would go back up to the Bronx and go to our neighborhood library and a lot of my students showed up to read with me ... I really made myself available to those families . . . the bigger picture of why I'm a teacher is social justice, student achievement, giving students what my teachers gave to me ... I want to be a teacher that will work with really high poverty students, or students ... who are low-income students of color ...

Teaching is not simply a job for most teachers (Alsup, 2006; Britzman, 1986; Chong \& Low, 2009); teachers teach because they believe in making a difference in their students' lives. Yet, for Bounmy and Mai-Li, there is an added layer of motivation. They recognize that low-income students deserve the same high quality teaching that higherincome students automatically receive. For them, teaching is an act of social justice because by committing to working with low-income students, they are disrupting normative discourses about who deserves a high quality education. To Bounmy and Mai-Li, teaching is also about more than just being in the classroom. It is about investing in their students' lives - in monetary ways, such as by funding a student's college application fee, and also with time, by meeting students in their neighborhood, outside of school to foster relationships with them and their families. 
Both teachers are motivated to teach for social justice because it is a way for them to give back to students in whom they see themselves. But, what are the complexities surrounding a social justice teaching agenda? What does it mean for an Asian American teacher to work in low-income neighborhoods when racial discourses have marked them as financially successful? How is it perceived when an Asian American teacher teaches in a school where the majority student population is Latino or Black? Are they viewed as fellow people of color, or are they and their motivations viewed as suspect?

\section{Class, Race, Gender, and Role-Modeling}

It is important to consider how Bounmy and Mai-Li's intersectional identities both facilitate their acceptance by and prevent them from fitting into their school communities. Intersectionality acknowledges and affirms the interactions between race, class, gender, and other social positions in shaping identity and relationships. First conceptualized and coined by Black feminist scholars as a way to understand the "triple oppression" of African American women (Crenshaw, 1989) who lack race, gender, and class privilege, Asian American feminists have borrowed from this idea to describe their own double or triple oppression (Shah, 1997). Asian American scholars also make use of the concept of intersectionality to resist the discourse that Asian Americans are a homogeneous group (Yanagisako, 1994). Instead, by focusing on differences in gender, class, and sexuality among Asian Americans, scholars are able to have a more productive conversation about the heterogeneity (Lowe, 1991) of the Asian American experience.

Bounmy and Mai-Li are both very proud of their Lao and Vietnamese backgrounds, respectively. Both also recognize their gender identities as women. On being an Asian American female math teacher, Bounmy says,

It was the female mathematicians that took interest in me . . . I don't think it's because I'm Asian, I think it's more because I was a woman . . yes, I'm aware of the advantages that come with [being Asian American] in my field. But there are also disadvantages . . . you're either overlooked or you're the center of attention. There's no middle with the Asian American and woman.

Bounmy's observations of what it is like to be marked in a racialized and gendered body reflect the complexities of having an intersectional identity where neither identity confers privilege (as a woman of color). Bounmy's statement also speaks to the tensions associated with the model minority stereotype - that while her racial appearance may mark her as being gifted in math, her gendered appearance may not. So, while Bounmy's area of expertise reifies one stereotype, it contests another.

Of all of their multiple identities, Bounmy and Mai-Li's connections with their students and their goals of teaching for social justice are largely facilitated by their class identities. For example, Bounmy says:

You could say [I'm] quite proud of my journey. But I don't think it has anything to do with me being Asian. It's more of a journey about growing up poor and beating the odds. 
Mai-Li also comments:

I think about class where I come from and how I relate to my students on a much larger, more prominent level than I do about my race. I tend to feel like I don't even think about my race and all I think about is class.

For these teachers, class is a much more salient identity in their professional lives than any of their other identities. It is possible that this is because they have only taught in low-income neighborhoods, and because they do not teach students of the same ethnic backgrounds. (Bounmy has worked with African American and African immigrant students, and Mai-Li has worked with mostly Latino students and Black students. Though Mai-Li has taught Chinese students, she says she would feel more strongly connected to Vietnamese students.) The salience of class identity might also be a product of the fact that as students, both teachers' experiences were strongly shaped by class. Earlier, I provided examples of how Bounmy and Mai-Li's teachers supported them through monetary means: by helping them look for scholarships, and by using their own money to buy them things, like a lacrosse stick. Bounmy also stresses that her journey is about "beating the odds" more than anything else.

And yet, although Bounmy and Mai-Li believe that their class identities afford them with a unique connection to their students, this connection is not always or has not always been mutual. Bounmy recalls that before students in her school knew her background and reputation, they thought she was a "privileged, adopted Asian child." She says, "I remember someone said, 'who do you think you are? You're going to come save us...but after that now everybody that knows me knows what I'm all about. I'm this teacher who grew up where you grew up." This anecdote highlights the complexities of being an Asian American teacher. Despite the fact that Bounmy perceives herself as "one of them" with respect to her students, her racial identity is regarded as suspect (Achinstein \& Aguirre, 2008), and she must negotiate the "borderlands" (Alsup, 2006) that exist between these differing racial communities.

Her students view Bounmy vis-à-vis two prominent discourses associated with Asian Americans. First, they assume that she is adopted because she speaks unaccented English, which speaks to the idea that Asian Americans are "forever foreigners" (Tuan, 1998; Wu, 2003), and will never be authentic Americans. Her students' best explanation for her perfect English is adoption by White Americans, or "authentic" Americans, which speaks to the pervasiveness of this discourse. Secondly, her students label her as a privileged outsider based on her appearance. Without knowledge of how she grew up, her students use the model minority stereotype as a lens through which to make sense of her racial identity. They assume that because she is Asian American, she is privileged. It is only after she has speaks of her own struggles that her students accept her as one of them, and the advice that she gives them.

Both teachers rely on the discourse of "beating the odds" to guide their teaching goals and to motivate their students. Mai-Li talks extensively about being a "change agent." She says: 
I'm going to be the teacher that...helps turn their life around and I'm gonna be the person who cares for them even when no one else cares for them...I've also realized that having come from that, having came from that background I have a much better understanding of what parents need and what students need...I have that privilege of being able to see where they're coming from because I've also been there so I want to continue that... and if I have that understanding, like it's almost my responsibility...to be able to give back to that community.

Mai-Li, who has left her government subsidized housing community by achieving educational success (her parents still live there), believes that she is equipped to help other students do the same, and that she is uniquely positioned to do so because of her personal experience. She believes that if she was able to be successful with prompting from her teachers, she can do the same for her students, or even more, because she knows what it is like to be from "that background." Though Mai-Li does not share stories about her life with her students, perhaps because they are still young, she shares her cell phone number with students' parents and encourages them to call her whenever they need to, an action that demonstrates she is willing to go above and beyond what is required of her by her job. MaiLi resists the ideologies of "subtractive schooling" (Valenzuela, 2012) and instead rolemodels how education outside of the classroom, through personal relationships with students' parents, can yield success.

Bounmy takes a more explicit approach, perhaps because her students are older, and relays the stories that she has shared with them. For example, she says:

[I tell them] I'm this teacher who grew up where you grew up. I always let them know specific stories about-I used to chase after the city bus at night because I would be studying so late and we didn't have a car and I didn't want to wake up my parents. And I would tell them about hardships that I faced so they could at least appreciate the effort that I'm trying to do for them. Some of them wouldn't get it the first time around, but I do notice that they get it eventually.

Bounmy repeatedly tells stories to teach her students about succeeding in school and in life. In utilizing this "critical storytelling" (Hartlep \& Hensley, 2015) pedagogy with students, she attempts and succeeds at legitimizing her identity as one of them. It is through her stories of running after the bus that she is able to convince her students that she is just like them and therefore trustworthy. Bounmy believes that by telling and showing her students how she succeeded, they will find success too.

Role-modeling is central to these teachers' pedagogies. Their visions of teaching are based on reaching out to students who grew up the way they did-without social capital or much access to educational opportunities. Both Bounmy and Mai-Li believe that they succeeded because of their own teachers' investments in them, and they believe if they invest in their students, they will yield similar outcomes. Thus, they have made it their mission to teach in low-income neighborhoods, to serve students of color, and to make themselves available to these students and their families. Through implicit and explicit role-modeling, Mai-Li and Bounmy have positioned themselves to help their students find academic success. Through these actions, both teachers resist the discourse of the model minority stereotype that frames Asian American students as successful and all other 
students of color as low-achieving. They help to re-frame the conversation around lowincome students and students of color and advocate that all students can be high achievers.

However, it is useful to examine their intentions not only with respect to the shared class status they have with their students, but also with respect to their dissimilar racial experiences. That is, although Asian American students are given the benefit of the doubt, even when they are struggling in class (Nance, 2007), Black and Latino students are not. Are Bounmy and Mai-Li aware of these differences? Do they acknowledge the privilege that comes with being Asian American in educational settings, and do they recognize that their Black and Latino students do not share these privileges? Bounmy and Mai-Li are intimately familiar with what it takes to overcome financial barriers, language barriers, and the challenges of being first-generation college students. Because of this, they are equipped to serve low-income students. But, is an understanding of class inequalities sufficient, or do they also need to know how to navigate the complexities of class-race identities and barriers in order to help their students?

\section{Reflections on Race, Class, Gender, and Teaching}

As indicated earlier, I invited Bounmy and Mai-Li to respond to the first three sections to help me further understand how race has (and has not) played a role in their educational experiences, both as students and teachers. Here are their responses.

\section{On Being an Asian American Student}

Bounmy reflects:

I don't think it [my teachers supporting me] had to do with me being Asian . . . I remember that many of us [of different racial backgrounds] were given support . . . I feel like I have way more of an awareness in my graduate school years as far as differences in academic performance, differences in opportunity and access . . . when I was younger I . . . I guess the only difference I really noticed was like we spoke different languages. I didn't really notice that we were treated differently in that Asians were treated differently than Hispanics or Blacks. But I did notice that [there] were definitely an overwhelming number of let's say, more White students than there were other students in certain classes, yes ... There were a lot of White students, and there were a few Asian and fewer Blacks. So in that sense I did notice. But as far as like the details of it, I would say it wasn't until later when I became a teacher that I realized how big of a gap there really is in achievement.

Bounmy maintains that her teachers supported her because of her "desire to learn" and her eagerness as a student. And yet, looking back, she remembers that the classes she was placed in were not evenly represented with respect to race, though it was not until many years later that she realized why. Although Bounmy's race may not have had much to do with why her teachers invested in her education, race did play a role in shaping the broad landscape of her educational experience, with regards to who was allowed to be in 
certain classes. It was something Bounmy did not have to pay attention to, both because of her Asian background and because she was an honors student. Thus, although the discourse of the model minority may not have played an explicit role in Bounmy's educational opportunities, I would argue that it operated in indirect ways to shield her from the educational inequalities that other students of color face. This in itself is a privilege.

Mai-Li explains why she became a teacher - to serve students like her brother, who did not get the attention that he needed to do well in school.

I . . grew up in a high-poverty family, didn't have a lot of resources, but I was a really good student so my teachers really paid attention to me. And my brother, even though we grew up in the same family, he was a tough kid-he wasn't the best student, he didn't have like behavioral issues at school, but he really struggled academically ... they didn't support him whereas they supported me.

Mai-Li attributes her teachers' efforts to the fact that she was a student who showed promise, and who was eager to learn. Her brother, who did not display the same qualities, did not get the same attention. One way to read this story is that Mai-Li's teachers recognized her potential because she was a good student.

A second way to interpret this story is to understand that it was easy for Mai-Li's teachers to dote on her because she fit their framework for what a good student looks likeshe was eager, bright, and additionally, she was Asian American. However, because her brother was not the same kind of student, he did not get the attention she did. The model minority stereotype hurts struggling students because they do not get the attention they need (Lee, 2009; Nance, 2007; Thorstensson, 2013). When teachers assume that Asian American students are good students, the ones who need more help do not get assistance and suffer academically. Therefore, it is possible that Mai-Li's brother did not warrant his teachers' attention because he did not excel, and also did not fit the stereotype.

It is difficult to assess whether the model minority stereotype influenced how Bounmy and Mai-Li's teachers treated them without speaking to the teachers themselves. However, it is worth considering that Bounmy and Mai-Li benefitted from fitting into this mold - they were both good students, and this behavior reinforced what teachers are taught to think about Asian American students. Additionally, it is important to ponder how Bounmy's abilities and perhaps her race operated to shield her from the educational inequities that other students of color faced.

\section{On Whether Being Asian American Matters in Teaching Black and Latino Students}

I have already detailed how Bounmy's students view her as privileged, and how they assume she is an adopted Asian child before they learn where she grew up. Bounmy further explains:

I wouldn't say [hardships and inequalities are] more emphasized for Black students than Asian students because I grew up in a neighborhood with a lot of Asian gangs, and I grew up in a neighborhood where there were Black students, and they weren't in gangs. So I don't want to compare exactly, but will say that that's what I think 
makes the rapport piece so important. When I teach I always share my story, my background because I don't look like them. I don't...look like I have something in common with them, but when I share where I grew up with them, which is... literally ... blocks away [from where they live]... So it wasn't difficult for them to relate or have that rapport with me.

As I explained earlier, although Bounmy's students do not accept her immediately, once they learn about how and where she grew up, she is able to build rapport with them. Because being Asian American serves as a barrier between Bounmy and her students, her class status and childhood experiences end up being the point of connection she is able to make with her students. Bounmy's narrative speaks to the importance of "intersectionality" (Crenshaw, 1989; Crenshaw, 1991; Shah, 1997). Does being Asian American benefit Bounmy in society as compared to her Black students? Certainly. Even they believe she is privileged. However, Bounmy and her students view her experiences through a race-class lens, where race and class are held in equal weight to each other in determining Bounmy's life experiences, in shaping her pedagogy, and in how her students view her. The inequalities that Bounmy has faced as a low-income student of color who grew up "in a neighborhood with a lot of Asian gangs" matter more in her classroom context than the color of her skin.

Bounmy acknowledges and recognizes racial and gender differences, but explains that holding her students to high standards, rather than dwelling on their lack of privilege is the key to her pedagogical approach:

I don't want to say I don't see color when I teach because I definitely see color. I definitely see background; I definitely see religion, I hear it. But what I will say is when you teach students, you want to teach them as if they were going to be either (a) your own children, (b) children of presidents and celebrities. If you teach people in general-not just students-with dignity and with respect, and that they can do great things - guess what? They do great things.

Thus, because the model minority stereotype does not operate within the confines of her classroom, and all students are recognized as having potential, she is able to turn low-scoring students into high-scoring students who have high levels of conceptual understandings of math. While Bounmy does not explicitly address issues of privilege and inequity in her classroom, she believes that her approach in holding all students to a standard of excellence and providing them with the support that they need to reach levels of proficiency, and later, excellence, that she is able to overcome the negative perceptions her students may have internalized from the educational system.

Mai-Li has a slightly different experience now that she has moved back to Seattle and works with Latino, Black, and Vietnamese students. She explains that in New York City, her Vietnamese background did not have as much of an impact on her teaching, both because her students were younger, and because she did not work with any Vietnamese students. Thus, her point of connection with her Latino and Black students in New York City was based on a common socioeconomic experience, and it worked - just as this point of connection works for Bounmy. However, at her current school in Seattle, Mai-Li struggles with having the same level of connection with all of her students. She explains: 
When I was in New York . . . I taught a majority Latino and Black students . . But now our...school in Seattle ... . is different and so I do have a lot of Asian students that I very much connect to, and I connect to their families. But then it's been hard to connect with my African-American and Hispanic students.... And feel like I tell my story like everyday.... And when I talk to parents, like especially with parents that we ... want to recruit for our school. Like they really are interested in why we do this work. And there's a lot of trust that happens . . . and so I always tell them like I grew up in this neighborhood, and I had the privilege and opportunity to go to college and to move away, and to have options in my life. And so many of my friends who also grew up in this neighborhood, in this community, did not have that option. And so I do tell my story for parents to help them think long-term about what is possible for their children, and kind of like what needs to happen for their kids to get there.

Just as with Bounmy, Mai-Li has to make a case to her Black and Latino students that she understands their experiences, even if it does not look like she does. Her story of beating the odds in the same neighborhood that these students are from goes a long way in making connections. And yet, there is still a lot of negotiating around race that she must do because they are from dissimilar backgrounds. Instead of having to negotiate borderlands (Alsup, 2006) with respect to White racialized spaces, she and Bounmy work to negotiate the racialized lines across various communities of color. Her students do not yet have the knowledge that Bounmy's high school students have about the model minority stereotype and the means through which to racialize her through this lens. Instead, as younger children, they engage in a more overt process of othering their teacher. Mai-Li explains:

There were many incidences this year where like I had students who [were saying] Asian slurs. And I . . like when I think about like how do I support those students in understanding that saying that is the same as any racial comment ... I'm the only Asian American teacher on our staff right now . . . I don't think that others could have had the impact that I did in teaching and support those students in understanding a lot of the Asian racial things that they were doing and not understanding, right? And so it may be like at the middle-school level, kids are exploring and doing things that I didn't see at the elementary level, and I think it is imperative for them to be exposed to different types of teachers from all different races. And I think it's important for all different kind of teachers to be on campus to directly address racial slurs, whatever is coming up, to directly address it with the students.

Mai-Li's students may not have the language with which to express their suspicions (Achinstein \& Aguirre, 2008) of her yet, but their actions speak otherwise. Mai-Li struggles with how to reconcile the differences with how she is able to more easily connect with her Vietnamese students versus her Black and Latino students. Thus, being Asian American does matter in these subtle ways. On whether Mai-Li explicitly addresses issues of difference, privilege, and inequity with her students, she says: 
We are working on that ... conversations around equity and where we come from. Like we try to have these conversations on the reality of what it is . . I know kids at the middle school like are really angry about [the stats on graduating], and so we're starting to bridge those conversations . . . we talk a lot about our mission at our school, and why our school exists.

Although not fully developed, Mai-Li and her colleagues are beginning to cultivate strategies for talking with students about the educational inequities that they have faced, and how to overcome them. They make their students aware that this school is different from others because it was founded to support the academic achievement of underserved students.

Ultimately, however, what matters is that Bounmy and Mai-Li have made conscious efforts to forge a point of connection with their students. They understand that although they are from similar class backgrounds as their students, their different racial experiences can prevent their students from seeing that they grew up in the same neighborhoods as their students did. Thus, they work hard to build relationships with their students and their students' families so that their students understand theirs goals to help them succeed. Similar to what Ladson-Billings (1994) has found in culturally relevant teachers of African American students, Bounmy and Mai-Li have shown themselves to be excellent teachers of students of color because they "believe all students can succeed" (Ladson-Billings, 1994, p. 44) and they "see themselves as part of the community, see their

teaching as giving back to the community" (Ladson-Billings, 1994, p. 38). By expecting excellence from their students and more importantly, providing the support these students need to achieve excellence, Bounmy and Mai-Li implicitly and explicitly show their students that race and class need not be a barrier to academic success, even if others have said otherwise.

\section{Conclusion}

Asian Americans do not get to choose when they will be stereotyped as a model minority and when they will not. This racial discourse is pervasive and influences the ways in which Asian Americans are perceived by themselves and others. However, Asian Americans do get to choose when they will reify this stereotype and when they will disrupt it. Both Bounmy and Mai-Li have chosen to reframe the conversation around who they themselves are, and who their students are. Both teachers demonstrate that their educational successes are not attributed to one's race, but rather to educational opportunity and support. Additionally, both teachers resist using the model minority stereotype to understand themselves or their Black and Latino students, and instead insist that all students can be high-achieving when they are given appropriate resources and held to high standards. Moreover, both teachers have seized the opportunity to re-frame how their students view Asian Americans, such as when Bounmy challenges the idea that she is "privileged" and "adopted," and when Mai-Li tells her students how their racial slurs impact her.

Bounmy and Mai-Li have the advantage of sharing a class background with their students, which has given them firsthand knowledge in how to build rapport with their 
students and students' parents. But, this does not mean that only teachers of low-income backgrounds can serve low-income students, nor does it mean that only teachers of the same racial background can successfully serve students of the same background (Banks \& Banks, 2009; Gay, 2002; Howard, 2006; Ladson-Billings, 1994; Matias, 2013; Nieto, 2000; Sleeter, 1996; Villegas \& Lucas, 2007). Bounmy and Mai-Li demonstrate how Asian American teachers can be excellent teachers to all students of color.

Bounmy and Mai-Li's narratives provide ideas on how teachers from any background can teach for social justice. Their narratives demonstrate that (a) teachers must have a willingness to believe that their students can succeed and that (b) teachers must be willing to support their students in achieving excellence. Additionally, (c) both Bounmy and Mai-Li advise teachers to examine themselves and their privilege before teaching students of any background. Bounmy advises:

I was and am in a position to build that rapport because my background naturally allowed me to be in tune with their needs - so someone who is from a different background would need to definitely reflect on how their privilege affects their relationship from expectations and beliefs about students. Then actions will follow ... Beliefs are difficult to change but I also know excellent teachers who do not come from similar backgrounds as their students but they create access and opportunities through building relationships.

Mai-Li recommends:

I would tell them to be vulnerable to who they are, where they come from, and how they're going to be challenged by students, by families . . . in their race and their privilege. And then I would say that they have to be open-minded to learn from others, and to learn from their students, and then to never stop reflecting and taking a step back on things that happen during the school day that trigger them. And I think at the end of the day, what matters is our ability to in the moment you do the best that you can with what you know. But then never being afraid to go back and reflect on it, and seek help. I think so many times, like we're trying to connect with the student from different cultural backgrounds and we get embarrassed or we shut down . . . But we don't stop to be like, OK, how can I educate myself or who can I reach out to, to support me in understanding this student and where they're coming from.

Teaching is personal work, and it is a profession in which one's identity will be challenged (Alsup, 2006). While the model minority stereotype produces moments of tensions for Bounmy and Mai-Li, they continue to disrupt this discourse by making it their mission to serve low-income students of color and teach their students that they are more than just a stereotype. All teachers can be effective teachers of social justice if they, too, are willing to invest in students, support their academic growth, and constantly reflect on how their identities and experiences intersect with their pedagogical approaches. 


\section{References}

Achinstein, B., \& Aguirre, J. (2008). Cultural match or culturally suspect: How new teachers of color negotiate sociocultural challenges in the classroom. Teachers College Record, 110(8), 1505-1540.

Achinstein, B. \& Ogawa, R. T. (2011). Change(d) agents: New teachers of color in urban schools. New York: Teachers College Press.

Alsup, J. (2006). Teacher identity discourses: Negotiating personal and professional spaces. Mahwah, NJ: Lawrence Erlbaum Associates, Inc.

Arce, J. (2004). Latino bilingual teachers: the struggle to sustain an emancipatory pedagogy in public schools. International Journal of Qualitative Studies in Education, 17(2), 227-246.

Banks, J. A., \& Banks, C. A. M. (Eds.). (2009). Multicultural education: Issues and perspectives. Hoboken, NJ: John Wiley \& Sons.

Britzman, D. (1986). Cultural myths in the making of a teacher: Biography and social structure in teacher education. Harvard Educational Review, 56(4), 442-457.

Brown, A. L. (2009). "Brothers gonna work it out:" Understanding the pedagogic performance of African American male teachers working with African American male students. Urban Review, 41, 416-435.

Chiang, A., Fisher, J., Collins, W., \& Ting, M. (2015). (Mis)Labeled: The challenge of academic capital formation for Hmong American high school students in an urban setting. Journal of Southeast Asian American Education and Advancement, 10(1), $1-35$.

Chong, S., \& Low, E. L. (2009). Why I want to teach and how I feel about teachingformation of teacher identity from pre-service to the beginning teacher phase. Educational Research for Policy and Practice, 8(1), 59-72.

Chow, C.J. (2014). Raced Curriculum: Asian American College Students' Lives. In B. Ngo\& K. K. Kumashiro (Eds.), Six lenses for anti-oppressive education: Partial stories improbable conversations (2nd ed.)( pp. 85-98). New York: Peter Lang.

Clark, E. R., \& Flores, B. B. (2001). Who am I? The social construction of ethnic identity and self-perceptions in Latino preservice teachers. The Urban Review, 33(2), 6986.

Connelly, F. M., \& Clandinin, D. J. (1999). Shaping a professional identity: Stories of educational practice. New York: Teachers College Press.

Cozart, S. C. (2010). Becoming whole: A letter to a young, miseducated black teacher. Urban Review, 42(1), 22-38.

Crenshaw, K. (1989). Demarginalizing the intersection of race and sex: A Black feminist critique of antidiscrimination doctrine, feminist theory and antiracist politics. The University of Chicago Legal Forum, 140, 139-168.

Crenshaw, K. (1991). Mapping the margins: Intersectionality, identity politics, and violence against women of color. Stanford Law Review, 43(6), 1241-1299.

Creswell, J. W. (2009). Research design: Qualitative, quantitative, and mixed method approaches (3rd ed.). Thousand Oaks, CA: Sage.

Dickar, M. (2008). Hearing the silenced dialogue: An examination of the impact of teacher race on their experiences. Race, Ethnicity \& Education, 11(2), 115-132.

Espiritu, Y. L. (1992). Asian American panethncity: Bridging institutions and identities. 
Philadelphia: Temple University Press.

Farrugio, P. (2009). Bilingual education: Using a virtual guest speaker and online discussion to expand Latino preservice teachers' consciousness. Multicultural Education, 17(1), 33-37.

Frederick, R. M., \& View, J. L. (2009). Facing the rising sun: A history of black educators in Washington, DC, 1800-2008. Urban Education, 44, 571-607.

Foster, M. (1997). Black teachers on teaching. New York: The New Press.

Gay, G. (2002). Preparing for culturally responsive teaching. Journal of Teacher Education, 53(2), 106-116.

Goodwin. A. L., Genishi, C., Asher, N., \& Woo, K. A. (2006). Voices from the margins: Asian American teachers' experiences in the profession. In C. C. Park, R. Endo, \& A. L. Goodwin (Eds.), Asian and Pacific American education: Learning, socialization, and identity (pp. 99-120). Charlotte, NC: Information Age Publishing.

Gomez, M. L., Rodriguez, T. L, \& Agosto, V. (2008). Who are Latino prospective teachers and what do they bring to U.S. schools? Race, Ethnicity, and Education, 11(3), 267-283.

Gordon, J. (2000). Asian American resistance to selecting teaching as a career: The power of community and tradition. The Teachers College Record, 102(1), 173-196.

Hanna, P. (2012). Using internet technologies (such as Skype) as a research medium: A research note. Qualitative Research, 12(2), 239-242.

Hartlep, N. D. (2013). The model minority stereotype: Demystifying Asian American success. Charlotte, NC: Information Age Publishing.

Hartlep, N. D., \& Hensley, B. O. (Eds.). (2015). Critical storytelling in uncritical times: Stories disclosed in a cultural foundations of education course. Rotterdam, The Netherlands: Sense.

Hayes, C., \& Hartlep, N. D. (Eds.). (2013). Unhooking from whiteness: The key to dismantling racism in the United States. Rotterdam, Netherlands: Sense.

Howard, G. R. (2006). We can't teach what we don't know: White teachers, multiracial schools. New York: Teachers College Press.

Kim, C. J. (1999). The Racial triangulation of Asian Americans. Politics \& Society, 27(1), 105-138.

Knowles, J. G. (1992). Models for understanding pre-service and beginning teachers' biographies: Illustrations from case studies. In Goodson, I. F. (Ed), Studying teachers' lives (pp. 99-152). New York: Teachers College Press.

Ladson-Billings, G. (1994). The dreamkeepers: Successful teachers of African American children. San Francisco: Jossey-Bass Publishers.

Lareau, A. (2011). Unequal childhoods: Class, race, and family life. Berkeley, CA: University of California Press.

Lee, S. J. (2005). Up against whiteness: Race, school, and immigrant youth. New York: Teachers College Press.

Lee, S. J. (2009). Unraveling the "model minority" stereotype: Listening to Asian American youth, second edition. New York: Teachers College Press.

Lowe, L. (1991). Heterogeneity, hybridity, multiplicity: marking Asian American differences. Diaspora: A Journal of Transnational Studies, 1(1), 24-44.

Matias, C. E. (2013). Check yo'self before you wreck yo'self and our kids: 
Counterstories from culturally responsive white teachers?... to culturally responsive white teachers. Interdisciplinary Journal of Teaching and Learning, 3(2), 68-81.

Mensah, F. M. (2009). A portrait of black teachers in science classrooms. Negro Educational Review, 60(1-4), 39-52.

Miller, D. M. (2008). Shades of gray: an autoethnographic study of race in the academy. International Journal of Qualitative Studies in Education, 21(4), 347-373.

Morita-Mullaney, T., \& Greene, M. C. S. (2015). Narratives of Asian/American educators: A case study of resistance and rhetoric. In N. D. Hartlep (Ed.), Modern societal impacts of the model minority stereotype (pp. 291-322). Hershey, PA: IGI.

Nance, M. (2007). Unmasking the model minority myth. Diverse Issues in Higher Education, 24(22), 10-11.

National Center for Education Statistics: Total number of public school teachers and percentage distribution of school teachers, by race/ethnicity and state: 2011-12. (2011). Retrieved

from https://nces.ed.gov/surveys/sass/tables/sass1112_2013314_t1s_001.asp

National Commission on Asian American and Pacific Islander Research in Education (CARE). (2015). 2015 CARE repor. Retrieved from http://www.apiasf.org/research/2015_CARE_Report.pdf

Newton, R. M. (2003). Racialized experiences of Asian American student teachers. In C. C. Park, A. L. Goodwin, \& S. J. Lee. (Eds), Asian American identities, families, and schooling (pp. 77-104). Charlotte, NC: Information Age Publishing.

Nieto, S. (2000). Placing equity front and center some thoughts on transforming teacher education for a new century. Journal of Teacher Education, 51(3), 180-187.

Ngo, B. (2010). Unresolved identities: Discourse, ambivalence, and urban immigrant Students. Albany, NY: State University of New York Press.

Nguyen, H. T. (2009). Conceptions of teaching by five Vietnamese American preservice teachers. Journal of Language, Identity \& Education, 7(2), 113-136.

Ochoa, G. L. (2007). Learning from Latino reachers. San Francisco: Jossey-Bass.

Ogbu, J. U. (1987). Variability in minority school performance: A problem in search of an explanation. Anthropology \& Education Quarterly, 18(4), 312-334.

Okihiro, G. Y. (1994). Margins and mainstreams. Seattle: University of Washington Press.

Patton, M. Q. (2001). Qualitative Research and Evaluation Methods. Thousand Oaks, CA: Sage.

Philip, T. M. (2012). Asian American as a political-racial identity: Implications for teacher education. Race Ethnicity and Education, 17(2), 219-241.

QuickFacts United States: People. (n.d.) Retrieved from https://www.census.gov/quickfacts/table/PST045215/00

Prashad, V. (2000). The karma of brown folk. Minneapolis: University of Minnesota Press.

Rong, X. L., \& Preissle, J. (1997). The continuing decline in Asian American teachers. American Educational Research Journal, 34(2), 267-293.

Saldaña, J. (2009). The coding manual for qualitative researchers, Thousand Oaks, CA: SAGE Publications Inc.

Shah, S. Introduction: Slaying the Dragon Lady: Toward an Asian American feminism. 
(1997). In S. Shah (Ed), Dragon ladies: Asian American feminists breathe fire (pp. X11-XXI). Boston: South End Press.

Sheets, R. H., \& Chew, L. (2000). Absent from the research, present in our classrooms: Preparing culturally responsive Chinese American teachers. Journal of Teacher Education 53(2), 127-141.

Sleeter, C. E. (1996). Multicultural education as a social movement. Theory Into Practice, 35(4), 239-247.

Suzuki, G. M. (1998). Hidden in the margins: Perspectives and experiences of Asian American teachers about race, teaching, and diversity. (Doctoral dissertation). Available from Proquest Dissertions and Theses database. (UMI No. AAT 9906755).

Takaki, R. (1989). Strangers from a different shore: A history of Asian Americans. Boston: Little, Brown and Company.

Thorstensson, L. (2013). Learning English and "smartness": Refugee students negotiate language, reception, and ability in school. Journal of Southeast Asian American Education and Advancement, 8(1), 9-16.

Tuan, M. (1998). Forever foreigners or honorary whites?: The Asian ethnic experience today. New Brunswick, NJ: Rutgers University Press.

Valenzuela, A. (2012). Subtractive schooling: US-Mexican youth and the politics of caring. Albany, NY: State University of New York Press.

Villegas, A. M., \& Lucas, T. (2007). The culturally responsive teacher. Educational Leadership, 64(6), 28-33.

Wells, K. (2011). Narrative inquiry. New York: Oxford University Press.

Wong, M. G. (1980). Model students? Teachers perceptions' and expectations of their Asian and White students. Sociology of Education, 53(4), 236-246.

Wong, N. A. (2008). "They see us as resource": The role of a community-based youth center in supporting the academic lives of low-income Chinese American youth. Anthropology and Education Quarterly, 39(2), 181-204.

Wu, F. (2003). Yellow: Race in America beyond Black and White. New York: Basic Books.

Yanagisako, S. (1994). Transforming Orientalism: Gender, nationality, and class in Asian American studies. In S. Yanagisako \& C. Delaney (Eds.), Naturalizing power: Essays in feminist cultural analysis (pp. 275-298). New York: Routledge. 


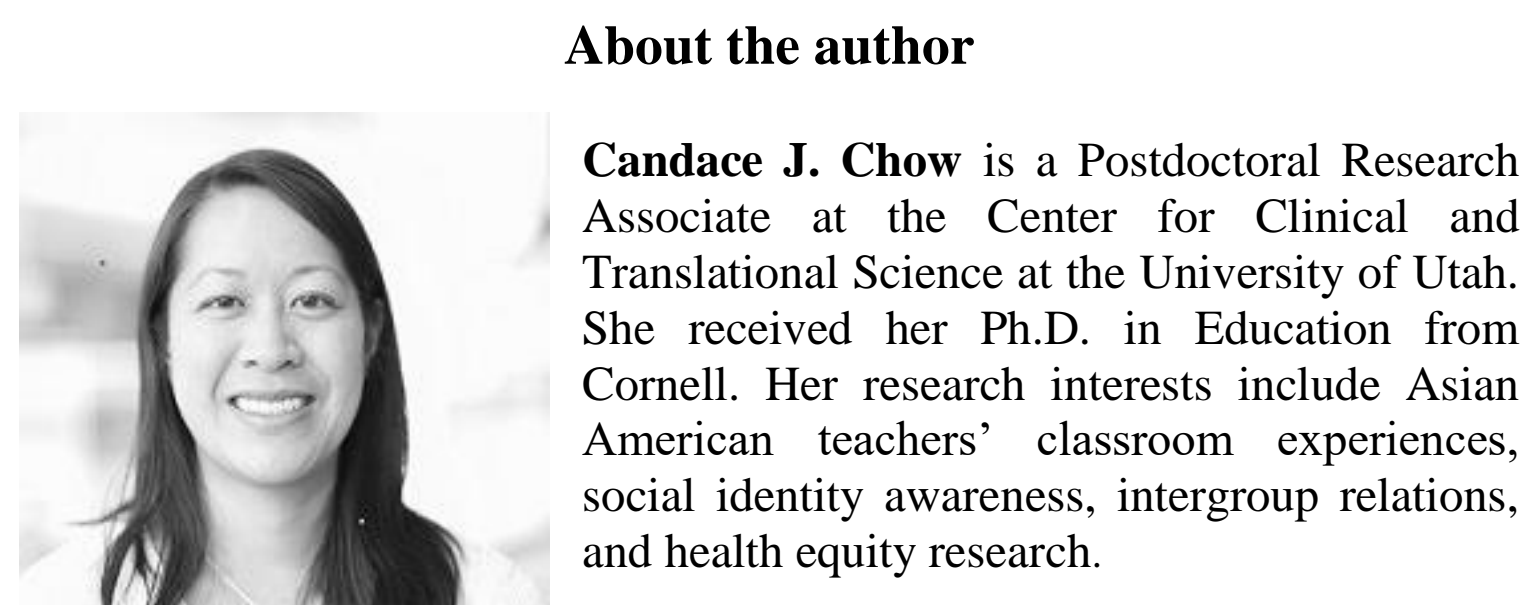




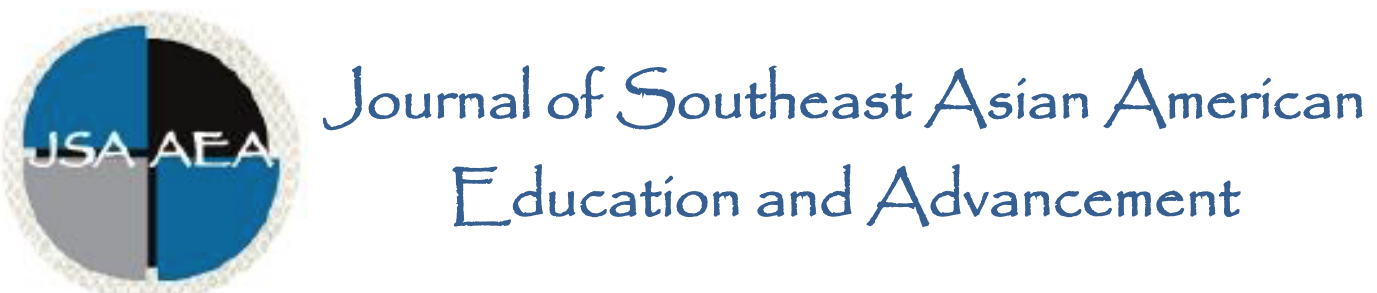

Vol.12 Iss.2 Special Issue (2017) www.JSAAEA.org

Special Issue Editor

Dr. Nicholas Hartlep

Metropolitan State University

Editor

Dr. Wayne E. Wright

Purdue University

Associate Editors

Dr. Chhany Sak-Humphry

University of Hawaii at Manoa

Dr. Phitsamay Sychitkokhong Uy
University of Massachusetts, Lowell

Book Review Editor

Dr. Vichet Chhuon

University of Minnesota

Creative Works Editor

Bryan Thao Worra

Lao Assistance Center

Journal Manager

Sung Ae Kim

Purdue University

\section{Editorial Review Board}

\author{
Dr. Steve Arounsack \\ California State University, Stanislaus \\ Dr. Sovicheth Boun \\ The State University of New York, \\ Fredonia \\ Dr. George Chigas \\ University of Massachusetts, Lowell
}
Dr. Carl L. Bankston III
Tulane University
Dr. Angela Reyes

Hunter College, The City University of New York

Dr. Loan Dao

University of Massachusetts, Boston 
Dr. Hien Duc Do

San Jose State University

Dr. Sophal Ear

Occidental College

Dr. Virak Chan

University of Texas at San Antonio

Dr. Jeremy Hein

University of Wisconsin, Eau Claire

Dr. Nancy H. Hornberger

University of Pennsylvania

Dr. Peter Nien-Chu Kiang

University of Massachusetts, Boston

Dr. Ha Lam

Eastern Mennonite University

Dr. Jonathan H. X. Lee

San Francisco State University

Dr. Monirith Ly

Royal University of Phnom Penh

Dr. Bic Ngo

University of Minnesota

Dr. Leakhena Nou

California State University, Long Beach

Dr. Mark Pfeifer

SUNY Institute of Technology

Dr. Loan T. Phan

University of New Hampshire

Dr. Kalyani Rai

University of Wisconsin, Milwaukee

Dr. Cathy J. Schlund-Vials

University of Connecticut, Storrs

Dr. Nancy J. Smith-Hefner

Boston University

Dr. Yer J. Thao

Portland State University

Dr. Monica M. Trieu

Purdue University

Dr. Silvy Un

Saint Paul Public Schools

Dr. Terrence G. Wiley

Center for Applied Linguistics
Dr. Changming Duan

University of Missouri, Kansas City

Dr. Sothy Eng

Lehigh University

Dr. Zha Blong Xiong

University of Minnesota

Dr. Vincent K. Her

University of Wisconsin, Eau Claire

Dr. Peter Tan Keo

New York University

Dr. Kevin K. Kumashiro

University of San Francisco

Dr. Ravy Lao

California State University, Los Angeles

Dr. Stacey Lee

University of Wisconsin, Madison

Dr. Sue Needham

California State University, Dominguez Hills

Dr. Max Niedzwiecki

Daylight Consulting Group

Dr. Clara Park

California State University, Northridge

Dr. Giang Pham

University of Massachusetts

Dr. Karen Quintiliani

California State University, Long Beach

Dr. Phala Chea

Lowell Public Schools

Dr. Fay Shin

California State University, Long Beach

Dr. Christine Su

Ohio University

Dr. Alisia Tran

Arizona State University

Dr. Khatharya Um

University of California, Berkeley

Dr. Linda Trinh Vo

University of California, Irvine

Dr. Yang Sao Xiong

University of Wisconsin-Madison 


\section{Doctoral Student Editorial Review Board}

\author{
Anna H. Yang \\ University of Georgia \\ Annie BichLoan Duong \\ San Joaquin County Office of Education \\ Hoa Nha Nguyen \\ Boston College \\ Malaphone Phommasa \\ Marshall University \\ Molly Wiebie \\ The University of Texas at Austin
}

\author{
Dung Minh Mao \\ University of Minnesota \\ Thien-Huong Ninh \\ University of Southern California \\ Krissyvan Truong \\ Claremont Graduate University \\ Soua Xiong \\ San Diego State University \& Claremont \\ Graduate University
}

